Copyright (C) 2016 by Academic Publishing House Researcher

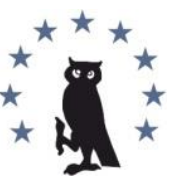

Published in the Russian Federation

European Researcher

Has been issued since 2010.

ISSN 2219-8229

E-ISSN 2224-0136

Vol. 109, Is. 8, pp. 462-467, 2016

DOI: 10.13187/er.2016.109.462

www.erjournal.ru

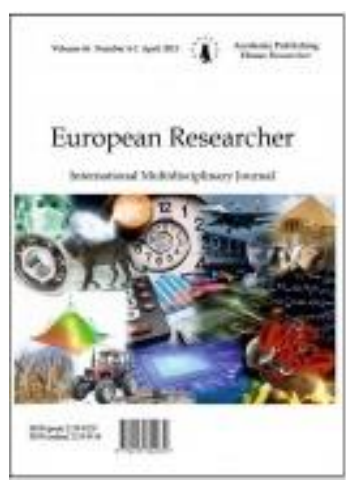

UDC 34

\title{
The Concept of "Decentralization"and its Various Interpretations
}

\author{
Habiba M. Zhurabekova
}

Andijan state university, Uzbekistan

Usta Shirin Str., 80, Andijan city 170137

Applicant

E-mail: tj2211@inbox.ru

\section{Abstract}

This article discusses the concept of "decentralization" and its definition. The author dwells on the different opinions of scientists on issues of decentralization and tries to find the main core of this concept. Analyzing different opinions concluded scientists that despite the different interpretations of the concept of decentralization, all scientists will eventually converge into a single view that decentralization - this is the gradual transfer of certain powers and functions of the central state authorities to the local authorities. The issue of decentralization has become one of the main areas of the Republic of Uzbekistan after independence policies. Activities of government began considered as one of the basic institutions of civil society. The country started a radical transformation and began allowing the gradual transfer of certain functions of the problem of local government to the executive power bodies.

Keywords: decentralization, democratic state, civil society, public institutions, Central and local authorities.

\section{Введение}

Человеческое общество с каждым днём меняется, развивается и обретает всё новые и новые изменения. Главной целью развития гражданского общества является создать необходимые условия для реализаций прав и свобод каждого гражданина общества, обеспечить участие каждого члена общества в разрешении разных проблем местного характера. Децентрализация способствует усилению активизации гражданских инициатив и создаёт более благоприятные условия для непосредственного участия граждан в общественно-политической жизни общества.

Наша основная цель - изучение понятия "децентрализация". Объектом изучения данной статьи является мнения и определения различных учёных этого понятия и разные её интерпретации, обобщение разных трактовок этого понятия. Научная новизна этой статьи заключается в том, что нет готовой модели децентрализации. Но на всех уровнях и во всех странах успех децентрализации зависит от активного участия граждан в жизни общества. Именно правильный подход и осуществление процесса децентрализации обеспечивает эффективность системы управления. 


\section{Материалы и методы}

В данной статье мы пользовались методами описания, контекстуального анализа, сравнения и сопоставления. На основе сопоставления идёт обобщение и конкретизация понятия.

\section{Обсуждение и результаты}

Децентрализация даёт возможность членам общества реализовать свои идеи и возможности, исходя из необходимой ситуации. Развитие должно осуществляться в интересах самих граждан и их усилиями. Путём активного участия органов местного самоуправления, неправительственных организаций и других институтов гражданского общества децентрализация создаёт широкие возможности для участия граждан в принятии решений, влияющих на их жизнь. Активное участие населения в общественных процессах повышает эффективность и предсказуемость принимаемых решений и проводимой политики, а это, в конечном итоге, обеспечивает устойчивость доходов населения и их возможностей.

"Централизация" и "децентрализация" играют важную роль в не только в политической жизни государства, но и в обеспечении условий развития гражданского общества.

Понятия децентрализация изучается разными учёными и каждый старается более подробно рассматривать этот процесс.

В. Робсон рассматривает процесс как “изменение структуры и финансирования местной власти, изменение отношений между центральной и местной властью, передача полномочий управления местным представительным органам”. Он считает, что “децентрализация должна обеспечивать местные органы управления самостоятельными полномочиями и повысить ответственность государственных служащих» [1, с. 76-164].

Японский учёный М. Мураматсу исследует вопрос децентрализации, исходя из Модели Ивасаки по децентрализации, где анализируется три уровня децентрализации. Он считает, что в целом все модели децентрализации практически действенны. Но они в основном основаны на юридическую теорию и в них политическая концепция очень ограничена. [2, c. 205]

По мнению В. Васильева децентрализация является важнейшим механизмом эффективного управления. Автор рассматривает процесс децентрализации как "децентрализация решений". При этом он подчёркивает, «если речь идёт о демократическом государстве, то это государство должно дать свои полномочия местным органам до такого уровня, что использование этих полномочий должны принести огромные результаты в интересах общества. Процесс децентрализации в демократических и тоталитарных государствах существенно отличается. При тоталитарном государстве этот процесс не осуществляется до конца и не даёт желаемого результата. Он осуществляется всего лишь на бумагах и это ограничивает творческий подход местной власти, вся работа осуществляется на основе определённых стандартов. В свою очередь, население тоже не старается особенно активизировать свои действия, и, если смотреть на это со стороны, то жизненный уровень населения остаётся одинаковым для всех. В демократических государствах осуществление мер по децентрализации сопровождается активным участием всего населения, в результате чего с каждым днём улучшается жизненный уровень того или иного народа» $[3$, с. 9$]$.

Как отмечает Т. Фаллети, децентрализация - это, «в первую очередь, совокупность действий, которые осуществляются самим же государством при передаче определённых компетенций центральной власти местным органам управления». При этом автор подчёркивает, что здесь «процесс децентрализации не включает в себя передачу функций негосударственным организациям» [4, с. 3-27].

По определению В. Рональда и С. Пола децентрализация - это взаимоотношение центральных и местных органов управления в следующих трёх взаимосвязанных отраслях: полномочия;

1. Экономическая отрасль, которая требует большие административные и финансовые

2. Качественные социальные услуги, которые требуют развития взаимоотношений местных органов и с центральными и с региональными органами власти;

3. "Эффективное государственное управление" [5, с. 95-178]. 
В английском эквиваленте "эффективное государственное управление" звучит как "good governance" и означает следующее:

- во-первых, при "good governance" государственное управление строится на основе распределения власти, народной власти, избрания высоких чиновников, отчёта исполнительных органов власти, преимущества закона, политического плюрализма и самостоятельности средств массовой информации;

- во-вторых, своевременное достижение высоких результатов на основе мудрого и экономичного использования социальных ресурсов. Всё это касается деятельности государственных служащих центральных и местных органов управления.

Экономист Г. Саидова считает, что «децентрализация предполагает передачу части функций от центральных к местным органам власти, расширение взаимодействия с институтами гражданского общества». [6, с. 5]

По определению С.Сафаева “децентрализация - это делегирование определённх функций государственного управления низовым структурам, местным органам власти. Приближение органов управления к объектам управления и через это повышение качества исполнения функций власти. Она включает в себя четыре главных вектора перераспределения функций и полномочий:

1. От исполнительной - к другим ветвям власти.

2. От центра к регионам.

3. От правительства - негосударственным экономическиам структурам.

4. От правительства - к гражданскому обществу" [7,с. 26].

Таким образом, децентрализации - это делегирование определённых (или некоторых) функций государственного управления низовым структурам, местным органам власти, а дальше -органам самоуправления граждан.

Децентрализация включает в себя:

- во-первых, процесс связанный с реформой государственной системы управления, с либерализацией и повышением эффективности управления, который осуществляется постепенно и долго;

- во-вторых, процесс, где путём передачи местным органам власти политическую власть, админстративные функции и финансовые обязанности меняется взаимотношения между центральными и местными органами власти;

- в-третьих, политический процесс, который связан с поэтапным созданием системы местных органов государственного управления, конечной целью которого является создание муниципальных структур управления.

При этом, учитывая сильные стороны процесса децентрализации, необходимо помнить и о слабых сторонах данного процесса(таблица 1).

Таблица 1. Сильные и слабые стороны децентрализации:

\begin{tabular}{|c|c|}
\hline СИЛЬНЫЕ СТОРОНЫ & СЛАБЫЕ СТОРОНЫ \\
\hline $\begin{array}{l}\text { Продвигает демократию, так как } \\
\text { децентрализация обеспечивает условия } \\
\text { для активного участия местных граждан в } \\
\text { процессах принятия решений }\end{array}$ & $\begin{array}{l}\text { Отсутствие контроля со стороны } \\
\text { центрального правительства может привести } \\
\text { к усилению риска движения местной элиты. } \\
\text { Это движение может принести вред } \\
\text { демократии }\end{array}$ \\
\hline $\begin{array}{l}\text { Повышает качество и эффективность } \\
\text { оказанных услуг. Передача полномочий } \\
\text { местным властям даёт возможность } \\
\text { минимализировать различные } \\
\text { официальные преграды } \\
\end{array}$ & $\begin{array}{l}\text { Отсутствие контроля может привести к } \\
\text { понижению качества оказанных социальных } \\
\text { услуг }\end{array}$ \\
\hline $\begin{array}{l}\text { Самостоятельность местного управления, } \\
\text { подотчётность перед избирателями и } \\
\text { способность оперативного отношения } \\
\text { возникшим проблемам даёт возможность } \\
\text { повысить качество социальных услуг }\end{array}$ & $\begin{array}{l}\text { Ограничение местных ресурсов и } \\
\text { возможностей оказывает отрицательное } \\
\text { влияние на качество социальных услуг }\end{array}$ \\
\hline
\end{tabular}




\begin{tabular}{|c|c|}
\hline $\begin{array}{l}\text { Понимание региональных возможностей } \\
\text { способствует ускоренному социально- } \\
\text { эконмическому развитию определённого } \\
\text { региона }\end{array}$ & $\begin{array}{l}\text { Интересы местного населения могут остаться } \\
\text { под угрозой развития коррупции и } \\
\text { межрегионального неравенства }\end{array}$ \\
\hline $\begin{array}{l}\text { Прозрачность в деятельности местной } \\
\text { власти обеспечивает своёвременную } \\
\text { подотчётность и возможность } \\
\text { своёвременного реагирования к } \\
\text { возникшим местным потребностям } \\
\text { населения }\end{array}$ & $\begin{array}{l}\text { Может привести к пустым обещанием, } \\
\text { которые могут дать местные власти не } \\
\text { учитывая свои возможности }\end{array}$ \\
\hline $\begin{array}{l}\text { Обеспечивает возможностью } \\
\text { равномерного учёта интересов в принятии } \\
\text { решений политических, этнических, } \\
\text { религиозных и культурных групп }\end{array}$ & $\begin{array}{l}\text { Может привести к усилению этнических и } \\
\text { религиозных конкуренций }\end{array}$ \\
\hline $\begin{array}{l}\text { Обеспечивает активное участие местных } \\
\text { граждан в осуществление социальных } \\
\text { программ на региональном уровне. } \\
\text { Повышает национальное единство и } \\
\text { обеспечивает политическую стабильность }\end{array}$ & $\begin{array}{l}\text { Неравномерное развитие регионов может } \\
\text { привести к социальному неравенству и } \\
\text { ослаблению государства. А это приведёт к } \\
\text { деградации национального управления } \\
\text { финансовыми ресурсами }\end{array}$ \\
\hline $\begin{array}{l}\text { Приведёт к внедрению новых } \\
\text { политических идей и прогрессивных } \\
\text { программ развития }\end{array}$ & $\begin{array}{l}\text { Усиление риска консерваторских взглядов } \\
\text { местной элиты может привести к ущербу } \\
\text { интересам возникшим от креативности } \\
\text { местной власти }\end{array}$ \\
\hline $\begin{array}{l}\text { Повышает активность, инициативу, } \\
\text { креативность и стремление к новаторству } \\
\text { представителей местного управления и их } \\
\text { избирателей }\end{array}$ & \\
\hline
\end{tabular}

Накануне нового тысячелетия в Республике Узбекистан в качестве приоритетных задач были определены новые задачи строительства гражданского общества, приняты ряд нормативных документов по демократизации и модернизации страны: в области государственного строительства и управления, по реформированию и дальнейшей либерализации судебно-правовой системы и деятельности средств массовой информации и общественных организаций. В стране были осуществлены ряд мер по пути участия граждан в социально-политических процессах, осуществляемых после обретения независимости. Когда речь идёт о процессах децентрализации и модернизации общества в Республике Узбекистан необходимо обратить внимание на труды Президента Республики Ислома Абдуганиевича Каримова, который стал инициатором всех реформ, осуществлённых и осуществляемых и по сей день в стране. Президент Республики в своих трудах как "Узбекистан по пути углубления экономических реформ"(1995), "Родина священна для каждого" (1996), "Узбекистан на пороге XXI века. Угрозы безопасности, условия и гарантии прогресса" (1997), "Концепция дальнейшего углубления демократических реформ и формирования гражданского общества в стране” (2010) и во многих других работах не раз подчёркивает о необходимости постепенной децентрализации и модернизации общества.

Долгосрочная концепция децентрализации и модернизации демократического общества был разработан по инициативе Президента Республики И.А.Каримова, исходя из мировой практики и из национальных особенностей узбекского народа, опирающийся на ценности общечеловеческого и национального развития. Как отмечает Ислам Каримов: “Достаточно много внимания уделялось вопросам децентрализации управления, передачи части функций от республиканского уровня органам областного, городского и районного уровня, формированию в Узбекистане такой уникальной системы местного самоуправления, как махалля" [8, с. 4]. Правительством Республики стало уделяться большое внимание на постепенную передачу функций и полномочий местным органам власти и органам самоуправления. 


\section{Заключение}

В последнее десятилетие во многих странах наблюдается постепенный переход к децентрализации - передача функций, полномочий и ответственности центральных государственных органов местным органам власти. Децентрализация всё больше рассматривается как процесс прямого вовлечения местных сообществ в формирование и финансирование общественных программ, повышения эффективности деятельности административной структуры власти.

Исходя из опыта развитых стран и анализируя мнения учёных, можем прийти к следующему выводу, что децентрализация - это долгий процесс, который должен осуществляться постепенно и систематично. Нет готовой модели децентрализации для определённого государства. Каждый народ и каждое государство, руководствуясь теорией и опытом международного сообщества, учитывая свои национальные особенности, может осуществить процесс децентрализации и строить демократическое общество.

\section{Литература} c. $76-164$.

1. Робсон В. Кризис местного правительства. Лондон: «George Allen Unwin LTD», 1966,

2. Мураматсу М. Местная власть в Японском государстве. Калифорния: «University of California Press, Ltd». 1997. c. 205.

3. Васильев В.И. Местное самоуправление. Учебное и научно-практическое пособие. М.: Юринформцентр, 1999. с. 9.

4. Фаллети Т. Последовательная теория децентрализации и его влияние на баланс сил во взаимоотношении между органами государственной власти: на примере Латинской Америки в сравнительной перспективе. 2004, c. 3-27. http://www.nd.edu/ kellogg/publications/workingpapers/WPS/314.pdf. (дата обращения 7 марта 2016 г.)

5. Рональд В. и Пол. Международный Банк Реконструкции и Развития Децентрализация в Восточной Азии. Вашингтон, 2005. с. 95-178.

6. Саидова Г. Вступительное слово // Национальный доклад о человеческом развитии,2005 // Децентрализация и человеческое развитие. Ташкент, 2006. ScanWeb, Финляндия, с. 5 .

7. Сафаев С. К вопросу децентрализации и совершенствовании государственного управления. // Жамият ва бошкарув. 2013. № 1. с. 26.

8. Каримов И.А. Концепция дальнейшего углубления демократических реформ и формирования гражданского общества в стране. Доклад на совместном заседании Законодательной палаты и Сената Олий Мажлиса Республики Узбекистан 12 ноября 2010 г. Ташкент: Ўзбекистон, 2010, с. 4.

\section{References}

1. Robson V. Krizis mestnogo pravitel'stva. London: «George Allen Unwin LTD», 1966, s. 76-164.

2. Muramatsu M. Mestnaya vlast' v Yaponskom gosudarstve. Kaliforniya: «University of California Press, Ltd». 1997, s. 205.

3. Vasil'ev V.I. Mestnoe samoupravlenie. Uchebnoe i nauchno-prakticheskoe posobie. Moskva: Yurinformtsentr, 1999, s.9.

4. Falleti T. Posledovatel'naya teoriya detsentralizatsii i ego vliyanie na balans sil vo vzaimootnoshenii mezhdu organami gosudarstvennoi vlasti: na primere Latinskoi Ameriki $\mathrm{v}$ sravnitel'noi perspektive. 2004, s.3-27. http://www.nd.edu/ kellogg/ publications /workingpapers/WPS/314.pdf. (data obrashcheniya 7 marta 2016 g.)

5. Ronal'd V. i Pol. Mezhdunarodnyi Bank Rekonstruktsii i Razvitiya Detsentralizatsiya v Vostochnoi Azii. Vashington: 2005, s. 95-178.

6. Saidova G. Vstupitel'noe slovo // Natsional'nyi doklad o chelovecheskom razvitii,2005 // Detsentralizatsiya i chelovecheskoe razvitie. Tashkent, 2006. ScanWeb, Finlyandiya, s. 5.

7. Safaev S. K voprosu detsentralizatsii i sovershenstvovanii gosudarstvennogo upravleniya. Zhamiyat va boshkaruv, № 1, 2013, s. 26.

8. Karimov I.A. Kontseptsiya dal'neishego uglubleniya demokraticheskikh reform i formirovaniya grazhdanskogo obshchestva $\mathrm{v}$ strane. Doklad na sovmestnom zasedanii 
Zakonodatel'noi palaty i Senata Olii Mazhlisa Respubliki Uzbekistan 12 noyabrya 2010 g. Tashkent: Y̌zbekiston, 2010, s. 4.

УДК 34

\title{
Понятие "децентрализация" и её различные трактовки
}

\author{
Хабиба Мадаминовна Журабекова
}

Андижанский государственный университет, Узбекистан

170137 г. Андижан, улица Уста ширин 80

Соискатель

E-mail: tj2211@inbox.ru

Аннотация. В статье рассматривается понятие «децентрализация» и её определения. Автор останавливается на различных мнениях учёных по вопросам децентрализации и старается найти основной стержень этого понятия. Анализируя различные мнения учёных делается вывод о том, что несмотря на различные трактовки понятия децентрализации, все учёные, в конечном итоге, сходятся в едином мнении, что децентрализация - это и есть постепенная передача некоторых полномочий и функций центральными государственными органами управления к органам местной власти. Вопрос децентрализации стал одним из основных направлений политики Республики Узбекистан после обретения независимости. Деятельность органов самоуправления стала рассматриваться как один из основных институтов гражданского общества. В стране начались коренные преобразования и постепено стали разрешать проблему передачи определённых функций местных органов исполнительной власти органам самоуправления.

Ключевые слова: децентрализация, демократическое государство, гражданское общество, общественные институты, центральные и местные органы власти, эффективное управление, участие граждан. 